\title{
Effect of Fine Coal Tailing Porosity on the Mobility and Speciation of Heavy Metals in the Leachates
}

\author{
Elvis Fosso-Kankeu*, Charl Olivier, Dumisane Moyakhe, Brad Barlow, Quentin Campbell and Frans \\ Waanders
}

\begin{abstract}
The effect of porosity of coal tailings on the mobilization and speciation of heavy metals is important for the implementation of management strategies. In this study, column leaching experiments were carried out to assess the mobilization of metal from coal tailings collected from a Witbank Stream 4 in the province of Mpumalanga, South Africa. Various parameters, including the $\mathbf{p H}$, RedOx potential (RP), electrical conductivity (EC), acidity and sulphate and chloride ion concentrations were analyzed to conduct the speciation of the heavy metals in the leachates. The mineralogical composition of the tailings were determined using X-ray diffraction (XRD) and the metal analyses were conducted using inductively coupled plasma-optical emission spectrometry (ICP-OES). Speciation of the heavy metals within the leachates were determined with PHREEQC modelling software. The XRD results indicated that, excluding quartz, pyrite was the dominant mineral, representing $6 \%$ of the sample. The ICP analysis indicated that the six major heavy metals leached were $\mathrm{Cd}, \mathrm{Co}, \mathrm{Mn}, \mathrm{Ni}, \mathrm{Pb}$ and $\mathrm{Zn}$, with $\mathrm{Mn}$ and $\mathrm{Zn}$ having the highest concentrations. The paste samples indicated higher concentrations of the pollutants in the leachate than that of the filter cake samples. The PHREEQC results indicated that free hydrated ion species were dominant in the leachates of the paste samples than the filter cakes, which indicates higher mobility and toxicity.
\end{abstract}

Keywords - Fine coal tailing, leaching, metal speciation, porosity.

\section{INTRODUCTION}

Extractive mining plays a vital role in our day to day lives, providing minerals we use on a daily basis. These processes do

E. Fosso-Kankeu is with the Water Pollution Monitoring and Remediation Initiatives Research Group in the School of Chemical and Minerals Engineering of the North West University, Potchefstroom-South Africa.

F. Waanders is with the Water Pollution Monitoring and Remediation Initiatives Research Group in the School of Chemical and Minerals Engineering of the North West University, South Africa

Charl Olivier is with the Water Pollution Monitoring and Remediation Initiatives Research Group in the School of Chemical and Minerals Engineering of the North West University, Potchefstroom-South Africa.

Dumisane Moyakhe is with the Water Pollution Monitoring and Remediation Initiatives Research Group in the School of Chemical and Minerals Engineering of the North West University, Potchefstroom-South Africa.

Brad Barlow is with the Water Pollution Monitoring and Remediation Initiatives Research Group in the School of Chemical and Minerals Engineering of the North West University, Potchefstroom-South Africa.

Quentin Campbell is with the Coal Research Group in the School of Chemical and Minerals Engineering of the North West University, Potchefstroom-South Africa. however, produce large amounts of waste materials, which are typically left as heaps or stored in tailings dams [1]. The waste material known as tailings, produced by the coal industry in South Africa usually contains about $8 \%$ iron disulphide, also known as pyrite $\left(\mathrm{FeS}_{2}\right)$ [2]. The weathering of the tailings over time, results in the formation of acid mine drainage (AMD), which is formed through the oxidation of the pyrite when it is exposed to water and oxygen [3-6-15]. Tailings is also known to contain traces of heavy metals, such as lead, zinc and arsenic [1]. The very acidic nature of AMD enables the dissolution of these heavy metals, which are transported into nearby streams and percolate into the groundwater. As a result, AMD has a big environmental impact, not only on the fauna and flora, but also humans who are dependent on these water sources for daily use [3; 16-32]. Speciation of the heavy metals within the leachates of the tailings, enables us to identify the toxicity and bioavailability of these metals [33 - 37]. The effect that the porosity of the tailings has on the mobilization of the heavy metals with the solution, has not yet been studied thoroughly. The scope of this project is thus to determine the effect the porosity of the tailings on the mobilization and speciation of the heavy metals within. This can provide significant information, which may prove of worth for the implementation of management strategies for tailing heaps and tailings dams.

\section{EXPERIMENTAL SETUP AND METHODOLOGY}

\section{A. Materials}

The coal tailings used for the experiment, were collected from a Witbank Stream 4 in the province of Mpumalanga, South Africa. The coal tailings, which was a paste, was stored in a tight seal plastic container before use.

\section{B. Mine tailings characterization}

In order to characterize the coal tailings, X-ray diffraction (XRD) analysis was carried out using the Philips X'Pert pro MPD X-ray diffractometer to determine the mineralogical composition. The particle size distribution was also determined using Malvern Master-sizer equipment.

\section{Synthetic acid rain production}

Synthetic acid rain was produced using 98\% sulphuric acid and $55 \%$ nitric acid. Sulphuric and nitric acids were mixed in a 
3:2 $\mathrm{ml}$ ratio, after which an adequate amount of this solution was diluted with $100 \mathrm{~mL}$ distilled water. The synthetic acid rain was produced by adding this buffer solution to $500 \mathrm{~mL}$ of distilled water until the reading on the $\mathrm{HI} 8424 \mathrm{pH}$ meter (Hanna Instruments Inc.) indicated a value of 4.2. A total of $3 \mathrm{~L}$ synthetic acid rain was produced using the abovementioned method.

\section{Column leaching experiments}

The equipment used for the leaching experiment consisted of twelve identical PVC columns. Six of the columns were packed with $800 \mathrm{~g}$ filter cakes, which were made from the coal tailings using a filter press. The remaining other six columns were filled with $800 \mathrm{~g}$ of the coal tailings paste. The experiment was done in triplicate, thus three of the filter cake columns as well as three of the paste columns were filled with $500 \mathrm{~mL}$ distilled water, which served as control samples. The other three columns of different porosity form were filled with $500 \mathrm{~mL}$ of the synthetic acid rain. The leachates of the columns were then collected on a weekly basis for eight consecutive weeks. The $\mathrm{pH}$, temperature, RedOx potential (RP) and the electrical conductivity (EC) were measured weekly, whereas the chloride ion concentration, acidity, sulphate concentration and metal analysis were determined on a monthly basis. The $\mathrm{pH}$, temperature and RP were measured using a HI $8424 \mathrm{pH}$ meter (Hanna Instruments Inc.), while the conductivity was measured using a Lovibond Sensodirect 150 meter. The HI 83099 COD and Multiparameter Photometer (Hanna Instruments Inc.) was used to measure the monthly sulphate ion concentrations. After the measurements were done, the leachate was thrown back into the top of the respective column.

\section{E. Titrations}

To determine the monthly chloride ion concentrations, titrations were conducted using a $0.02 \mathrm{M}$ silver nitrate $\left(\mathrm{AgNO}_{3}\right)$ solution. Potassium chromate $\left(\mathrm{K}_{2} \mathrm{CrO}_{4}\right)$ was used as an indicator. Titration with $0.02 \mathrm{M}$ sodium hydroxide $(\mathrm{NaOH})$ was conducted to determine the acidity of the leachates.

\section{F. Metal analyses}

For the monthly metal analyses, $1 \mathrm{~mL}$ leachate of each column was diluted to $20 \mathrm{~mL}$ using distilled water and then stored in the lab fridge at $4^{0} \mathrm{C}$. Inductively coupled plasma-optical emission spectrometry (ICP-OES) was then used to conduct the metal analysis.

\section{G. Speciation modelling}

The speciation of the dominant metals present within the leachates was determined using the PHREEQC interface (version 3.4.0-12927) with AQUACHEM software. The database that was used for the speciation is Minteq.v4.dat. According to Striggov (2013), the measured RP values were adjusted with a correction factor, and were then used to determine the $\mathrm{pE}$ values. To determine the speciation, the $\mathrm{pH}$, temperature, $\mathrm{pE}$ and the metals, $\mathrm{Cl}^{-}$and $\mathrm{SO}_{4}{ }^{2-}$ concentrations were used as the input data.

\section{RESULTS AND DISCUSSION}

\section{A. Particle size distribution}

The particle size distribution (PSD) of the coal tailings is given in Fig. 1. The PSD is given from 0.01 to $1000 \mu \mathrm{m}$, but from the figure it can be seen that the coal tailings' particles range from 0.8 to $160 \mu \mathrm{m}$. From the PSD results, it is given that $50 \%$ of the particles are smaller than $25.524 \mu \mathrm{m}$ and $90 \%$ of the particles are smaller than $116.877 \mu \mathrm{m}$. The coal tailings' particles are relatively small, which increases the surface area exposed to the leaching solution and the probability of heavy metals leaching out of the tailings.

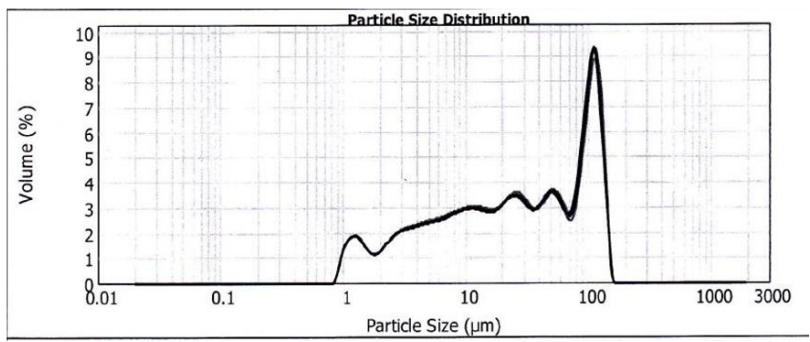

Fig. 1: Particle size distribution of coal tailings

\section{B. Mineralogical composition}

The results from the XRD analysis are given in TABLE I. Quartz is the most prominent mineral, being 45 weight percentage of the tailings. Wollastonite, which is calcium silicate (CaSiO3), also represents a large percentage of the sample; a total of $38.5 \%$. The tridymite, which is $8.77 \%$ of the sample, is also another form of quartz, resulting that silica minerals constitute $92 \%$ of the entire sample. Apart from the silica minerals, pyrite is the most abundant mineral, with a total of $6.1 \%$. This indicates that there was pyrite available for the oxidation reaction to form sulphuric acid. The tailings also contained small amounts of diopside and mackinawite.

TABLE I: MinerALOGICAL COMPOSITION OF COAL TAILINGS

\begin{tabular}{|l|r|}
\hline \multicolumn{1}{|c|}{ Mineral } & Weight \% \\
\hline Diopside & 1.431 \\
\hline Wollastonite-2M & 38.572 \\
\hline Tridymite & 8.773 \\
\hline Quartz low HP & 45.099 \\
\hline Mackinawite & 0.027 \\
\hline Pyrite & 6.099 \\
\hline
\end{tabular}

\section{C. $p H$ results}

Fig. 2 indicates the changes in the $\mathrm{pH}$ levels of the four different samples over the eight weeks' period. The standard deviations of $\mathrm{pH}$ values observed for the triplicate samples were smaller than $10 \%$, thus the average of these values were taken to represent the $\mathrm{pH}$ value of the four different samples each week.

The $\mathrm{pH}$ decreases gradually from week 1 to week 8, with the exception of the last week, which indicates a drastic increase in the $\mathrm{pH}$ levels of all four different samples. The initial $\mathrm{pH}$ values 
measured the first week varied from 3.5 to 3.1 and decreased to values between 2.5 and 2.7 , after which the $\mathrm{pH}$ values increased to values ranging from 3.0 to 3.2. The decrease in the $\mathrm{pH}$ levels for all four samples are very similar, which indicates that the oxidation reaction rate tends to be similar for all the samples.

However, it can also be seen that for both the porosities, the $\mathrm{pH}$ is lower for the samples being leached with water than with the synthetic acid rain. This indicates that the oxidation process is more predominant with water rather than with synthetic acid rain. The $\mathrm{pH}$ for both conditions, distilled water and synthetic acid rain, is lower for the paste versus the filter cake. The results indicate that the acidity of the synthetic acid rain doesn't have a big effect on the formation of AMD, but the porosity does. The sample with a higher porosity allows better oxidation and thus better formation of AMD.

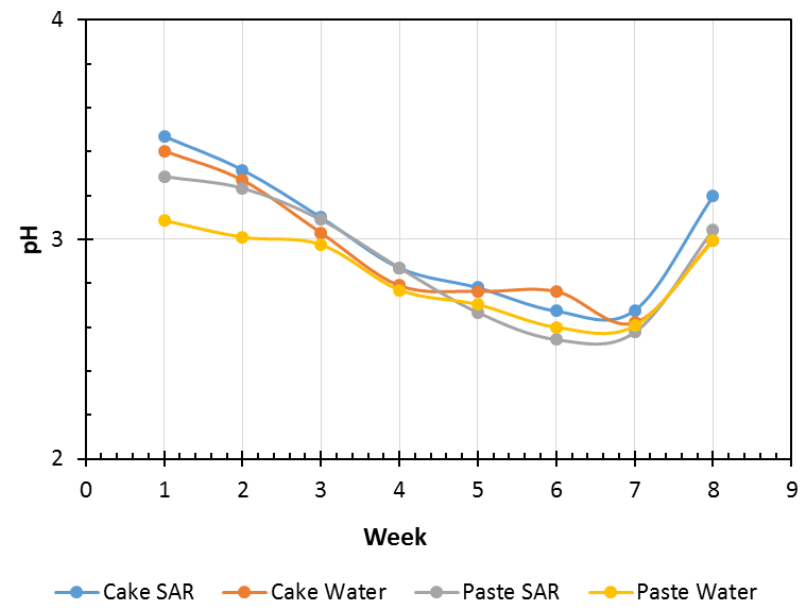

Fig. 2: Changes in $\mathrm{pH}$ levels

\section{Speciation results}

The metal speciation of the leachates is given in TABLE II. Only the speciation results for the two samples treated with synthetic acid rain are indicated in the table. From TABLE II it can be seen that most of the elements have either two or three dominant species present, with the exception of $\mathrm{Fe}^{3+}$ and $\mathrm{Mn}^{3+}$. For all the elements, any species representing less than one percent was excluded from the results since it does not contribute significantly to the sample representation, except for $\mathrm{Cl}$. The chloride is predominantly present as free ions $\left(\mathrm{Cl}^{-}\right)$, while the $\mathrm{Mn}^{3+}$ is only present as free ions. $\mathrm{Co}^{2+}, \mathrm{Fe}^{2+}, \mathrm{Mn}^{2+}, \mathrm{Ni}$ and $\mathrm{Zn}$ are all also mostly present as free ions with these species representing between $45 \%$ and $63 \%$ of the respective element. For these five elements, the second most prominent species for each are the sulphate complexes $\left(\mathrm{CoSO}_{4}, \mathrm{FeSO}_{4}, \mathrm{MnSO}_{4}\right.$, $\mathrm{NiSO}_{4}, \mathrm{ZnSO} 4$ ), ranging from $37 \%$ to $48 \%$ for each element. On the other hand, $\mathrm{CdSO}_{4}, \mathrm{FeSO}_{4}{ }^{+}$and $\mathrm{PbSO}_{4}$ are the dominant species for the $\mathrm{Cd}, \mathrm{Fe}^{3+}$ and $\mathrm{Pb}$, while the free ion species only represent $40 \%, 3 \%$ and $27 \%$ respectively. $\mathrm{Co}^{3+}$ is the only species with a different dominant species, i.e. $\mathrm{Co}(\mathrm{OH})^{2+}$, which represents $95 \%$ of the species and the free ions $\left(\mathrm{Co}^{3+}\right)$ only representing $4 \%$. As expected, $\mathrm{SO}_{4}{ }^{2-}$ is the dominant species for $\mathrm{S}^{6-}$ of the various leachates, ranging from $91 \%$ to $92 \%$ for week four and $94 \%$ to $95 \%$ for week eight.
Comparing the different porosities to each other for week four, it is found that the concentrations of the free ionic species are lower in the leachates of the paste samples leached with synthetic acid rain versus the filter cake samples. The concentrations of $70 \%$ of the inorganic complexes are higher in the leachates from the paste samples and the other for the filter cake samples.

When comparing the results for the different porosities, week eight indicate the exact opposite results as week four. The leachates from the paste samples leached with synthetic acid rain indicate higher concentrations of the free ionic species than the filter cake samples. The concentrations of $30 \%$ of the inorganic complexes are higher in the leachates of the paste samples treated with synthetic acid rain than the filter cakes.

Considering the results of the samples leached with synthetic acid rain for week four, there is generally little difference between the concentrations of the species in the leachates of all the samples, but the biggest variations occur between the $\mathrm{Fe}^{3+}$ species. Ninety-seven percent of all the species' concentrations differ less than $10 \%$ of their respective counterparts, with the one specie's concentration that does vary more than $10 \%$, occurring between the $\mathrm{Fe}^{3+}$ species. The biggest difference observed between the concentrations of a species for the different porosities is for the $\mathrm{Fe}\left(\mathrm{SO}_{4}\right)^{2-}$. The filter cake sample leached with synthetic acid rain indicates a $10 \%$ higher concentration than the paste sample. The filter cake sample also indicates a $7 \%$ higher concentration in the free ions $\left(\mathrm{Fe}^{3+}\right)$ than the paste samples.

From week eight's results, the same observations are made as with week four. Overall $78 \%$ of the species' concentrations differ less than $10 \%$ than their respective counterparts, with 72 $\%$ of the species' concentrations that vary more than $10 \%$ occurring between the $\mathrm{Fe}^{3+}$ species. All the $\mathrm{Fe}^{3+}$ species' concentrations differ more than $10 \%$ between the paste and filter cake samples. The biggest difference observed between the concentrations of a species for the different porosities is for the $\mathrm{Fe}(\mathrm{OH})_{2}{ }^{+}$. The filter cake sample leached with synthetic acid rain indicates a $36 \%$ higher concentration than the paste sample. The filter cake sample also indicates a $24 \%$ higher concentration in the free ions $\left(\mathrm{Fe}^{3+}\right)$ than the paste samples. 
Table II: Speciation Results Of The Dominant Metals Within The LEACHATES OF THE COAL TAILINGS

\begin{tabular}{|c|c|c|c|c|c|}
\hline Element & Species & \multicolumn{2}{|c|}{ Cake SAR } & \multicolumn{2}{|c|}{ Paste SAR } \\
\hline \multicolumn{2}{|c|}{$\begin{array}{l}\text { Leaching Time } \\
\text { (Weeks) }\end{array}$} & 4 & 8 & 4 & 8 \\
\hline \multirow[t]{4}{*}{ Cd } & $\mathrm{CdSO} 4$ & $40,62 \%$ & $40,36 \%$ & $41,39 \%$ & $40,17 \%$ \\
\hline & $C d+2$ & $41,01 \%$ & $38,11 \%$ & $39,92 \%$ & $38,67 \%$ \\
\hline & $\mathrm{Cd}(\mathrm{SO} 4) 2-2$ & $15,78 \%$ & $16,34 \%$ & $16,22 \%$ & $16,24 \%$ \\
\hline & $\mathrm{CdCl}+$ & $2,58 \%$ & $5,14 \%$ & $2,47 \%$ & $4,88 \%$ \\
\hline \multirow[t]{3}{*}{$\mathrm{Cl}$} & $\mathrm{Cl}-$ & $99,95 \%$ & $99,95 \%$ & $99,97 \%$ & $99,96 \%$ \\
\hline & $\mathrm{MnCl}+$ & $0,03 \%$ & $0,03 \%$ & $0,03 \%$ & $0,03 \%$ \\
\hline & $\mathrm{ZnCl}+$ & $0,01 \%$ & $0,01 \%$ & $0,01 \%$ & $0,01 \%$ \\
\hline \multirow[t]{2}{*}{$\mathrm{Co}(2)$} & $\mathrm{Co}+2$ & $59,37 \%$ & $58,33 \%$ & $58,69 \%$ & $58,67 \%$ \\
\hline & $\mathrm{CoSO} 4$ & $40,54 \%$ & $41,44 \%$ & $41,21 \%$ & $41,13 \%$ \\
\hline \multirow[t]{2}{*}{$\mathrm{Co}(3)$} & $\mathrm{CoOH}+2$ & $94,48 \%$ & $96,91 \%$ & $94,42 \%$ & $95,71 \%$ \\
\hline & $\mathrm{Co}+3$ & $5,05 \%$ & $2,57 \%$ & $5,08 \%$ & $3,58 \%$ \\
\hline \multirow[t]{2}{*}{$\mathrm{Fe}(2)$} & $\mathrm{Fe}+2$ & $54,79 \%$ & $53,61 \%$ & $53,94 \%$ & $54,02 \%$ \\
\hline & $\mathrm{FeSO} 4$ & $45,21 \%$ & $46,39 \%$ & $46,06 \%$ & $45,98 \%$ \\
\hline \multirow[t]{5}{*}{$\mathrm{Fe}(3)$} & FeSO4+ & $65,81 \%$ & $47,95 \%$ & $66,70 \%$ & $57,44 \%$ \\
\hline & $\mathrm{Fe}(\mathrm{SO} 4) 2-$ & $15,55 \%$ & $31,44 \%$ & $15,84 \%$ & $20,11 \%$ \\
\hline & $\mathrm{Fe}(\mathrm{OH}) 2+$ & $10,85 \%$ & $11,63 \%$ & $9,72 \%$ & $13,89 \%$ \\
\hline & $\mathrm{FeOH}+2$ & $4,27 \%$ & $6,68 \%$ & $4,50 \%$ & $5,67 \%$ \\
\hline & $\mathrm{Fe}+3$ & $3,46 \%$ & $2,26 \%$ & $3,21 \%$ & $2,81 \%$ \\
\hline \multirow[t]{2}{*}{$\operatorname{Mn}(2)$} & $M n+2$ & $62,71 \%$ & $61,50 \%$ & $61,87 \%$ & $61,92 \%$ \\
\hline & $\mathrm{MnSO} 4$ & $37,24 \%$ & $38,41 \%$ & $38,10 \%$ & $38,00 \%$ \\
\hline $\mathrm{Mn}(3)$ & $\mathrm{Mn}+3$ & $100,00 \%$ & $100,00 \%$ & $100,00 \%$ & $100,00 \%$ \\
\hline \multirow[t]{2}{*}{$\mathbf{N i}$} & $\mathrm{Ni}+2$ & $53,45 \%$ & $52,07 \%$ & $52,60 \%$ & $52,44 \%$ \\
\hline & $\mathrm{NiSO} 4$ & $46,42 \%$ & $47,70 \%$ & $47,29 \%$ & $47,33 \%$ \\
\hline \multirow[t]{3}{*}{$\mathrm{Pb}$} & $\mathrm{PbSO} 4$ & $62,02 \%$ & $61,58 \%$ & $62,02 \%$ & $61,62 \%$ \\
\hline & $\mathrm{Pb}+2$ & $27,52 \%$ & $26,52 \%$ & $27,11 \%$ & $26,71 \%$ \\
\hline & $\mathrm{Pb}(\mathrm{SO} 4) 2-2$ & $9,88 \%$ & $10,61 \%$ & $10,28 \%$ & $10,47 \%$ \\
\hline \multirow[t]{3}{*}{$S(6)$} & SO4-2 & $92,00 \%$ & $94,66 \%$ & $91,70 \%$ & $93,50 \%$ \\
\hline & HSO4- & $5,59 \%$ & $3,04 \%$ & $5,95 \%$ & $4,13 \%$ \\
\hline & $\mathrm{MnSO} 4$ & $1,80 \%$ & $1,69 \%$ & $1,68 \%$ & $1,68 \%$ \\
\hline \multirow[t]{3}{*}{ Zn } & $Z n+2$ & $45,84 \%$ & $44,18 \%$ & $44,85 \%$ & $44,59 \%$ \\
\hline & ZnSO4 & $43,44 \%$ & $44,28 \%$ & $44,10 \%$ & $44,00 \%$ \\
\hline & $\mathrm{Zn}(\mathrm{SO} 4) 2-2$ & $10,64 \%$ & $11,41 \%$ & $10,99 \%$ & $11,28 \%$ \\
\hline
\end{tabular}

\section{CONCLUSION}

The PSD results for the coal tailings indicate that the particles are relatively small ranging from 0.8 to $160 \mu \mathrm{m}$ in diameter. This created a large surface area exposed to the leaching solution, increasing the oxidation process. Besides quartz, the XRD indicates that pyrite is the dominant mineral, representing $6 \%$ of the tailings. The $\mathrm{pH}$ results indicate that the samples leached with distilled water (control sample) have a lower $\mathrm{pH}$ than those leached with the synthetic acid rain. The $\mathrm{pH}$ values of the paste samples are also lower than those of their respective filter cake counterparts. This indicates that the lixiviant used did not significantly contribute to the oxidation process, while the porosity of the sample had a significant effect. The lower porosity of the filter cake samples allowed less contact between the leaching solution and the pyrite contained within, resulting in less AMD produced. The PHREEQC speciation results indicate that the heavy metals occur mostly as free ionic species in the leachates of the paste samples than the filter cakes, but only after eight weeks. This indicates that the initial release of the metals is slow within four weeks and increases afterwards. This can be due to the metals being contained deep within the paste and the leachate needing time to reach the metals and cause the leaching. The higher concentrations of the free ionic species within the leachates of the paste samples indicate that the mobility of the heavy metals within these leachates are higher than that of the filter cake samples. Thus, the heavy metals leached from the paste samples have a higher toxicity and are a greater environmental concern $[2,38]$. Mine tailings with a high porosity which are exposed to natural weathering are of greater concern than tailings with a lower porosity.

\section{REFERENCES}

[1] Kossoff, D., Dubbin, W.E., Alfredsson, M., Edwards, S.J., Macklin, M.G. \& Hudson-Edwards, K.A. 2014. Mine tailings dams: Characteristics, failure, environmental impacts, and remediation. Applied Geochemistry, 51(1): 229-245. https://doi.org/10.1016/j.apgeochem.2014.09.010

[2] Elvis Fosso-Kankeu, Alusani Manyatshe, Frans Waanders. 2017. Mobility potential of metals in acid mine drainage occurring in the Highveld area of Mpumalanga Province in South Africa: Implication of sediments and efflorescent crusts. International Biodeterioration and Biodegradation. 119: 661-670. https://doi.org/10.1016/j.ibiod.2016.09.018

[3] Simate, G.S. \& Ndlovu, S. 2014. Acid mine drainage: Challenges and opportunities. Journal of Environmental Chemical Engineering, 2(1): 1785-1803

https://doi.org/10.1016/j.jece.2014.07.021

[4] Bell, F.G., Bullock, S.E.T., Hälbich. T.F.J. \& Lindsay, P. 2001. Environmental impacts associated with an abandoned mine in the Witbank Coalfield, South Africa. International Journal of Coal Geology, 45(1): 195-216. https://doi.org/10.1016/S0166-5162(00)00033-1

[5] Concas, A., Ardau, C., Cristine, A., Zuddas, P. \& Cao, G. 2006. Mobility of heavy metals from tailings to stream waters in a mining activity contaminated site. Chemosphere, 63(1): 244-253. https://doi.org/10.1016/j.chemosphere.2005.08.024

[6] Pinetown, K.L., Ward, C.R., van der Westhuizen, W.A., 2007. Quantitative evaluation of minerals in coal deposits in the Witbank and Highveld Coalfields, and the potential impact on acid mine drainage. International Journal for Coal Geology. 70(1): 166-183. https://doi.org/10.1016/j.coal.2006.02.013

[7] E. Fosso-Kankeu, A. Mulaba-Bafubiandi, B.B. Mamba, T.G. Barnard, Indigenous microorganism strains as bio-extractants of $\mathrm{Ca}, \mathrm{Fe}$ and $\mathrm{Mg}$ from metallurgical and mine drainages. The Southern African Institute of Mining and Metallurgy, Hydrometallurgy Conference 2009. Symposium Series S54, pp 93-100, 2009.

[8] E. Fosso-Kankeu, A. Mulaba-Bafubiandi, B.B. Mamba, T.G. Barnard, Assessing the effectiveness of a biological recovery of nickel from tailings dumps. Journal of Minerals Engineering. Vol. 24, pp. 470-472, 2011. https://doi.org/10.1016/j.mineng.2010.11.007 
[9] E. Fosso-Kankeu, R. Kaitano, F. Waanders, A.F. Mulaba-Bafubiandi, Soil Quality in the Basin of Mine Effluents and the Potential of Alleviation of Metal Dispersion. An Interdisciplinary Response to Mine Water Challenges. International Mine Water Conference, August 2014 Xuzhou China. Editors, Sui, Sun \& Wang (Eds). 2014 China University of Mining andTechnology Press, Xuzhou, ISBN: 978-7-5646-2437-8. Pp374-378. 2014.

[10] E. Fosso-Kankeu, F. Waanders, A.F. Mulaba-Bafubiandi and S. Sidu, Leachability of suspended particles in mine water and risk of water contamination. $10^{\text {th }}$ ICARD/IMWA 2015; $10^{\text {th }}$ International Conference on Acid Rock Drainage \& IMWA Annual Conference. 21-24 April 2015 Santiago-Chile. Editors: Adrian Brown, Charles Bucknam, Joanna Burgess, Manuel Carballo, Devin Castendyk, Linda Figueroa, Lisa Kirk, Virginia McLemore, James McPhee, Mike O'Kane, Robert Seal, Jacques Wiertz, David Williams, Ward Wilson, Christian Wolkersdorfer. ISBN: 978-956-9393-28-0. Chap 4. Pp 1-9. 2015.

[11] E. Fosso-Kankeu, F.B. Waanders, and A.H. Munyai, Susceptibility of Metals Release from Tailings Dumps Located In the Krugersdorp Area. $7^{\text {th }}$ International Conference on Latest Trends in Engineering and Technology (ICLTET' 2015), November 12-27, 2015 Irene, Pretoria (South Africa). Editors: E. Muzenda and T Yingthawornsuk. ISBN: 978-93-84422-58-5. 2015.

[12] A.H. Munyai, E. Fosso-Kankeu, F. Waanders, Biological influence on the mobility of metals from mine tailing dump located in Krugersdorp area. International Journal of Science and Research. ISSN: 2319-7064. Vol. 5, no. 4, pp. 1396-1403, 2016.

[13] A.H. Munyai, E. Fosso-Kankeu, F. Waanders, Mobility of metals from mine tailings using different types of organic acids: Batch leaching experiment. International Journal of Science and Research. Vol. 5, pp. 520-527, 2016.

[14] E. Fosso-Kankeu, A. Manyatshe, A. Munyai, F. Waanders, AMD formation and dispersion of inorganic pollutants along the main stream in a mining area. In: Drebenstedt, C. \& Paul, M.: IMWA 2016 - Mining Meets Water - Conflicts and Solutions. - p. 391 - 397; Freiberg/Germany (TU Bergakademie Freiberg). 2016.

[15] A.H. Munyai, E. Fosso-Kankeu, F. Waanders, Effects of organic acids on heavy metals released from mine tailings. International Conference on Advances in Science, Engineering, Technology and Natural Resources (ICASETNR-16) Nov. 24-25, 2016, Parys - South Africa. ISBN: 978-93-84468-79-8. 2016.

[16] Li, H. \& Ji, H. 2017. Chemical speciation, vertical profile and human health risk assessment of heavy metals in soils from coal-mine brownfield, Beijing, China. Journal of Geochemical Exploration, 183(1):22-32. https://doi.org/10.1016/j.gexplo.2017.09.012

[17] Fig, D. 2011. Surfaces and externalities: acid mine drainage on the Witwatersrand, South Africa. New South African Review.

[18] Durand, J.F. 2012. The impact of gold mining on the Witwatersrand on the rivers and karst system of Gauteng and North West Province, South Africa. Journal of African Earth Sciences, 68(1): 24-43. https://doi.org/10.1016/j.jafrearsci.2012.03.013

[19] Oelofse,S.H.H., Hobbs, P.J., Rascher, J. \& Cobbing, J.E. 2007. The pollution and destruction threat of gold mining waste on the Witwatersrand - A West Rand case study. Paper presented at the 10th International Symposium on Environmental Issues and Waste Management in Energy and Mineral Production (SWEMP), Bangkok, 11-13 December.

[20] Saria, L., Shimaoka, T. \& Miyawaki, K. 2006. Leaching of heavy metals in acid mine drainage. Waste Management \& Research, 24(1): 134-140. https://doi.org/10.1177/0734242X06063052

[21] Wagner, N.J. \& Hlatshwayo, B. 2005. The occurrence of potentially hazardous trace elements in five Highveld coals, South Africa. International Journal of Coal Geology, 63(1): 228-246. https://doi.org/10.1016/j.coal.2005.02.014

[22] McCarthy, T.S. 2011. The impact of acid mine drainage in South Africa. South African Journal of Science, 107(5): 1-7. https://doi.org/10.4102/sajs.v107i5/6.712

[23] E. Fosso-Kankeu, A. Mulaba-Bafubiandi, B.B. Mamba, T.G. Barnard, Mitigation of $\mathrm{Ca}, \mathrm{Fe}$, and $\mathrm{Mg}$ loads in surface waters around mining areas using indigenous microorganism strains. Journal of Physics and Chemistry of the Earth, Vol. 34, pp. 825-829, 2009. https://doi.org/10.1016/j.pce.2009.07.005
[24] E. Fosso-Kankeu, A.F. Mulaba-Bafubiandi, B.B. Mamba, L. Marjanovic, and T.G. Barnard, Optimising the removal by $\mathrm{b}$ subtilis and $b$ bacterium of metals found around mining areas: evaluation of the effect of physical and physiological parameters. In: Water Institute of Southern Africa \& International Mine Water Association: Proceedings, International Mine Water Conference. International Mine Water Association Conference, Pretoria 2009. ISBN: 978-0-9802623-5-3. 2009.

[25] E. Fosso-Kankeu, A.F. Mulaba-Bafubiandi, B.B. Mamba and T.G. Barnard, Prediction of metal-adsorption behaviour in the remediation of water contamination using indigenous microorganisms. Journal of Environmental Management. Vol. 92, no. 10, pp. 2786-2793, 2011. https://doi.org/10.1016/j.jenvman.2011.06.025

[26] E. Fosso-Kankeu, A.F. Mulaba-Bafubiandi, G. Tlou and L. Piater, The next step in the bioremediation of heavy metal polluted water: Development of suitable microbial-sorbent. International Mine Water Conference, October 2012 Bunbury-Australia (Award Winning Paper). Editors, McCullogh, Lund and Wyse. ISBN: 978-0-7298-0707-4. Pp. 593-599, 2012.

[27] E. Fosso-Kankeu, A. Manyatshe, D. van der Berg, N. Lemmer, F. Waanders, and H. Tutu, Contaminants in Sediments across the Mooi and Vaal Rivers Network in The Vicinity of Potchefstroom. $7^{\text {th }}$ International Conference on Latest Trends in Engineering and Technology (ICLTET' 2015), November 26-27, 2015 Irene, Pretoria (South Africa). Editors: E. Muzenda and T Yingthawornsuk. ISBN: 978-93-84422-58-5. 2015.

[28] E. Fosso-Kankeu, Investigation of the oxidation rate of sediments from AMD using humidity cell test. International Conference on Advances in Science, Engineering, Technology and Natural Resources (ICASETNR-16) Nov. 24-25, 2016, Parys - South Africa. ISBN: 978-93-84468-79-8. 2016.

[29] I.G. Erdogan, T. Moncho, E. Fosso-Kankeu, S.K.O. Ntwampe, F. Waanders, N. Hoth, A. Rand, B. Fourie, Hydrochemical Characteristics Of Open-Pit Groundwater From A Closed Metalliferous Mine In O'kiep, Namaqualand Region, South Africa. $9^{\text {th }}$ Int'l Conference on Advances in Science, Engineering, Technology \& Waste Management (ASETWM-17). 27-28 November 2017, Parys, South Africa. Editors: F. Waanders, E. Fosso-Kankeu, B. Topcuoglu, M. Plaisent, Y. Thaweesak. ISBN: 978-81-934174-6-1. Pp. 137-141. 2017.

[30] E. Fosso-Kankeu and J. Redelinghuys, Bacterial ecology of biofilms sustaining pollution by acid mine drainage near mining areas in Mpumalanga Province - South Africa. 11 ${ }^{\text {th }}$ ICARD/IMWA/MWD Conference "Risk to Opportunity". 10-14 September 2018 Pretoria, South Africa. C. Wolkersdorfer, L. Sartz, A. Weber, J. Burgess, G. Tremblay.ISBN: 978-0-620-80650-3 Vol 1 (2 volumes). 2018.

[31] E. Fosso-Kankeu, F.B. Waanders, F.W. Steyn, Removal of Cr(VI) and $\mathrm{Zn}$ (II) from an aqueous solution using an organic-inorganic composite of bentonite-biochar-hematite. Desalination and Water Treatment. Vol. 59, pp. 144-153, 2017.

[32] E. Fosso-Kankeu, H. Mittal, F. Waanders, S.S. Ray, Thermodynamic properties and adsorption behaviour of hydrogel nanocomposites for cadmium removal from mine effluents. Journal of Industrial and Engineering Chemistry. Vol. 48, pp. 151-161, 2017. https://doi.org/10.1016/j.jiec.2016.12.033

[33] Smith, K. \& Huyck, H., 1999. An Overview of the Abundance, Relative Mobility, Bioavailability, and Human Toxicity of Metals. The Environmental Geochemistry of Mineral Deposits, p30-70.

[34] Magalhaes, D., Baptista, D., da C. Marques, M.R. \& Buss, D.F. 2015. Metal bioavailability and toxicity in freshwaters. Environmental Chemistry Letters. p1-19.

[35] Sundaray, S.K., Nayak, B.B., Lin, S. \& Bhatta, D. 2011. Geochemical speciation and risk assessment of heavy metals in the river estuarine sediments - A case study: Mahanadi basin, India. Journal of Hazardous Materials, 186(1): 1837-1846. https://doi.org/10.1016/j.jhazmat.2010.12.081

[36] Magu, M.M., Govender, P.P. \& Ngila, J.C. 2016. Geochemical modelling and speciation studies of metal pollutants present in selected water systems in South Africa. Physics and Chemistry of the Earth, 92(1): 44-51. https://doi.org/10.1016/j.pce.2015.08.001

[37] VanBriesen, J.M., Small, M., Weber, C. \& Wilson, J. 2010. Modelling Chemical Speciation: Thermodynamics, Kinetics and Uncertainty. 
Modelling of Pollutants in Complex Environmental Systems. 2(1): 133-149.

[38] A. Manyatshe, E. Fosso-Kankeu, D. van der Berg, N. Lemmer, F. Waanders, H. Tutu, Metal speciation in the rivers around Potchefstroom based on seasonality. Water Environment Research. Vol. 90, no. 1, pp. $84-95,2018$.

https://doi.org/10.2175/106143017X15054988926587 